\title{
Data report: refined method for calculating percentages of kaolinite and chlorite from X-ray diffraction data, with application to the Nankai margin of southwest Japan'
}

Junhua $\mathrm{Guo}^{2}$ and Michael B. Underwood ${ }^{2}$

\section{Chapter contents}

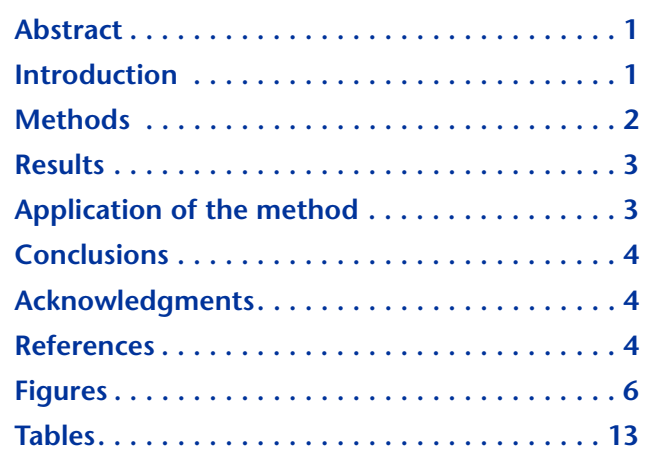

1Guo, J., and Underwood, M.B., 2011. Data report: refined method for calculating percentages of kaolinite and chlorite from X-ray diffraction data, with application to the Nankai margin of southwest Japan. In Kinoshita, M., Tobin, H., Ashi, J., Kimura, G., Lallemant, S., Screaton, E.J., Curewitz, D., Masago, H., Moe, K.T., and the Expedition 314/315/316 Scientists, Proc. IODP, 314/315/316: Washington, DC (Integrated Ocean Drilling Program Management International, Inc.). doi:10.2204/iodp.proc.314315316.201.2011 ${ }^{2}$ Department of Geological Services, University of Missouri, Columbia MO 65211, USA.

Correspondence author:

jg2kc@mail.missouri.edu

\section{Abstract}

Calculating accurate percentages of kaolinite and chlorite in marine sediments using X-ray diffraction (XRD) data is challenging because the minerals have similar d-values. Most approaches use a peak-intensity ratio or fitted-peak-area ratio and assume a linear fit between the ratio and the concentration of each mineral. To test this assumption, we mixed various proportions of kaolinite and chlorite standards and calculated each mineral's individual peak area (PA) at $\sim 3.5 \AA$ along with the total area (TA) of the composite peak. A power function provides the best correlation coefficient for regression curves of the ratio of PA/TA versus the actual mineral concentration (weight percent). The average error using a doubled half-peak area approach is $2.6 \%$. We tested the utility of the method by analyzing data from natural mudstone specimens from Ocean Drilling Program Sites 1177 and 1178 (central and western Nankai Trough). This documentation of temporal changes in concentrations of chlorite and kaolinite provides a basis for improved XRD analyses and interpretations of sediment provenance during the Integrated Ocean Drilling Program's Nankai Trough Seismogenic Zone Experiment.

\section{Introduction}

Semiquantitative analysis of clay minerals is commonplace in such fields as sedimentology, paleoceanography, and paleoclimate (e.g., Petschick et al., 1996; Svensson et al., 2000; Fagel et al., 2003; Liu et al., 2003). Most techniques are based on X-ray diffraction (XRD), but accurate quantitative analysis of clays and clay minerals remains a formidable challenge (Brindley, 1980; Reynolds, 1989; Snyder and Bish, 1989; McManus, 1991; Moore and Reynolds, 1997). It is difficult to reproduce with precision the intensities generated by broad reflections of poorly crystalline clay minerals, so researchers typically use values of peak area in combination with sets of weighing factors (Biscaye, 1965; Cook et al., 1975; Heath and Pisias, 1979; Fagel et al., 2003; Underwood et al., 2003). Accuracy improves if the analytical methods include calibration with internal standards, use of single-line reference intensity ratios, and some fairly elaborate sample preparation steps to ensure uniformity of random particle orientations (Środon et al., 2001; Omotoso et al., 2006). However, those kinds of approaches are too laborious to be practical for large suites of samples, such as those stemming from the Nankai Trough Seismogenic Zone Experiment (NanTroSEIZE). 
In marine geology, the most widely used factors for calculating percentages of smectite, illite, and kaolinite + chlorite were established by Biscaye (1965). Unfortunately, the d-values of kaolinite (001) and chlorite (002) reflections are nearly identical at $\sim 7 \AA$, as are the kaolinite (002) and chlorite (004) reflections at $3.5 \AA$. This overlap makes it difficult to separate peak intensities or peak areas before calculating their relative abundances. Heating to $550^{\circ} \mathrm{C}$ or boiling with hydrochloric acid helps to confirm the presence/absence of the two minerals (Nelson and Roy, 1953; Brindley, 1961; Martin Vivaldi and Gallego, 1961), but those steps are time consuming, and comparisons of peaks by subtraction of intensity or area values before and after treatment are flawed because two separate specimens are being analyzed, thereby propagating the error. Consequently, if a specimen contains both kaolinite and chlorite, completing XRD scans before and after the treatment cannot resolve the individual contents of either mineral very accurately.

Biscaye (1964) showed that the ratio of heights of the overlapping 7.16-7.08 $\AA$ peaks are approximately the same as the ratio of heights of the double peaks with d-values of 3.58-3.54 $\AA$. Most experts agree that the peaks at $\sim 3.5 \AA$ are better for semiquantitative analyses because of their slightly wider separation (e.g., Petschick et al., 1996; Fagel et al., 2003). The peak-intensity and fitted-peak-area ratios represent two ways to calculate the proportion of each mineral, although the fit between either one of the ratios and the true mineral abundance is nonlinear (Elverhøi and Rønningsland, 1978). Per unit weight, the kaolinite intensity is twice the chlorite intensity, so smaller contents of chlorite are detectable only as a shoulder on the double peak. To create better statistical fits and improve the XRD technique's accuracy, we mixed and analyzed standards of chlorite and kaolinite in known proportions by weight, and we computed two regression curves for the relation between peak-area ratio and weight percent. This report documents those test results and provides a thorough analysis of the error. By reducing the error, we hope to improve the detail and reliability of XRD results during NanTroSEIZE.

\section{Methods}

Two groups of standard minerals (C-group and $\mathrm{K}$ group) were mixed: a poorly crystalline kaolinite standard, Clay Minerals Society (CMS) KGa-1, and a variety of chlorite (ripidolite), CMS standard CCa-2. We selected those source clays standards because they are easily accessible to the research community and they have been thoroughly analyzed by other research (e.g., Chipera and Bish, 2001; Vogt et al., 2002). Proportions by weight are similar for the two groups of mixtures but not identical (Table T1). Prior to blending, each standard was suspended in $\sim 500 \mathrm{~mL}$ of distilled water with sodium hexametaphosphate dispersant and disaggregated using an ultrasonic cell disrupter. Particles $<2 \mu \mathrm{m}$ equivalent settling diameter were separated by centrifugation (1000 rpm for $2.4 \mathrm{~min} ; \sim 320 \times \mathrm{g}$ ). The average concentration of each suspension was determined by extracting three aliquots and drying at $75^{\circ} \mathrm{C}$ to obtain dry weight of clay per unit volume of suspension, corrected for weight of dispersant. The two components were measured by pipette and their volumetric proportions converted to dry weights and weight percentages (Table T1). Oriented aggregates on glass slides were prepared using the filter-peel method and $0.45 \mu \mathrm{m}$ membranes (Moore and Reynolds, 1997).

Working with an older analog diffractometer, Biscaye (1964) advocated the use of slow scanning rates $\left(0.2^{\circ} 2 \theta / \mathrm{m} ; 0.01^{\circ} 2 \theta\right.$ step $)$ to create higher intensity and reproducibility of the double peaks at $\sim 3.5 \AA$. We achieved optimal results with a faster scan $\left(1^{\circ} 2 \theta / \mathrm{m}\right.$; $0.01^{\circ} 2 \theta$ step) from $23^{\circ}$ to $28^{\circ} 2 \theta$. The instrument is a Scintag Pad V X-ray diffractometer with $\mathrm{CuK \alpha}$ radiation $(1.54 \AA)$ and a Ni filter, set to $40 \mathrm{kV}$ and $30 \mathrm{~mA}$. Slits were $0.5 \mathrm{~mm}$ (divergence) and $0.2 \mathrm{~mm}$ (receiving). We processed the digital data using MacDiff software (version 4.2.5) to establish a baseline of intensity, provide smooth counts, and correct for offset of peak positions caused by misalignment of the instrument's detector and small differences in the orientation of slides within the sample changer.

The uncorrected position of the kaolinite peak of interest ranges from $25.09^{\circ}$ to $25.19^{\circ} 2 \theta$, and the uncorrected chlorite peak ranges from $25.33^{\circ}$ to $25.48^{\circ} 2 \theta$. The peak positions were corrected to either kaolinite $(002)$ at $\sim 24.8^{\circ} 2 \theta$ (d-value $=3.58 \AA$ ) or chlorite $(004)$ at $\sim 25.1^{\circ} 2 \theta(\mathrm{d}$-value $=3.54 \AA)($ Fig. F1). The corrected peak profiles were used to locate the centers of peaks, from which the maximum intensities were determined. When both crests are resolved, angular separation between the two overlapping peaks averages $0.27^{\circ} 2 \theta$ (Fig. F1), which is consistent with synthetic diffractograms (e.g., Moore and Reynolds, 1997). Therefore, we always assumed that the crest of the subsidiary peak is separated from the crest of the dominant peak by $0.27^{\circ} 2 \theta$ when picking its point of maximum intensity on the shoulder of the composite (Fig. F1). In addition, we modeled the peaks using the Pearson II peak-fitting function of MacDiff on the corrected diffractogram to obtain the fitted area of those two peaks (Figs. F1, F2). The least residuum reduction was set to 0.001 , and the largest loop number of refinement was set at 100 .

On all the diffractograms generated for the standard mixtures (Fig. F3), we found that one side of the dominant peak is not distorted by interference from 
the minor peak. Using only the undistorted side makes it easy to compute the dominant peak's total area by multiplying its half-peak area by $2 \times$ (Fig. F2). One important assumption here is peak symmetry, which does not necessarily hold true for natural mixtures of clay minerals (Moore and Reynolds, 1997). Nevertheless, the ratio of the dominant peak area (PA) to the total area (TA) of the composite peak should correlate with each mineral's abundance. For mixtures in which both peak crests are distinct, each mineral's undistorted half-peak area was measured and doubled to compute both of the respective PA values.

\section{Results}

Tabulation of the results for standard mineral mixtures appears in Table T1. Regression analysis shows that a power function yields the best correlation coefficient $(r)$ for the ratio of PA to TA versus the known abundance of the mineral (Fig. F4). Linear regression, in comparison, shifts the intercept away from the origin, which is nonsensical. Two equations were constructed. For kaolinite-dominant specimens $\left(\right.$ kaolinite $\mathrm{wt} \%=100 \times(\mathrm{PA} / \mathrm{TA})^{1.613}$, where $\left.r=0.9870\right)$ and for chlorite-dominant specimens (chlorite wt $\%=$ $100 \times(\mathrm{PA} / \mathrm{TA})^{1.433}$, where $\left.r=0.9974\right)$. This pair of equations allows researchers a choice depending on which of the two minerals is dominant in the natural mix.

Table T1 also compares the calculated mineral abundances using three approaches (Fig. F5). The doubled half-peak area method yielded the best agreement between the calculated abundance and the actual abundance (Fig. F5). The maximum error is $7.7 \%$, and the average error is only $2.6 \%$. Using the intensity-ratio method, the average error increases to $7.4 \%$, but those results become more accurate with well-balanced proportions (chlorite to kaolinite ratio close to 50:50). Using the fitted-area-ratio method, the average error is $5.1 \%$, and those results are more reliable when kaolinite contents are between $20 \%$ and $80 \%$. The maximum errors increase to $17.6 \%$ and $12.3 \%$, respectively, using intensity-ratio and fittedarea-ratio (Table T1). Thus, for use with a broad range of potential mixtures in natural samples, the doubled half-peak area method is judged to be the most accurate.

Quantitative accuracy of XRD results is known to be affected by a long list of natural variables and laboratory artifacts, including the type of diffractometer, sample disaggregation technique, chemical pretreatment, particle size separation, size and shape distribution within a selected size fraction, chemical composition of clay minerals (e.g., content of iron in chlorite), structural ordering and crystallinity, the degree of preferred orientation of crystallites on the scanned surface, and peak-fitting algorithms (Reynolds, 1989; Moore and Reynolds, 1997; Ottner et al., 2000; Środon, 2002). Besides those variables, the thickness of aggregates on a glass slide will have some effect on the peak intensities and peak areas. This inconsistency in thickness helps explain the scatter of our results across similar ranges weight percentages for a given mineral (Fig. F3). Finally, we assumed ideal Pearson II peak shapes when computing the halfpeak areas, but the instrumental peak shape of a Bragg-Brentano diffractometer is usually somewhat asymmetric.

Unquestionably, the two CMS source clays KGa-1 (kaolinite) and CCa-2 (chlorite) are not representative of all possible clay mineral assemblages in natural marine sediments. The refinement probably could be improved even more by analyzing additional mixtures with a broader range of chemical compositions and crystallinities, particularly for chlorite, but then extra attention would be required to match by iteration each natural assemblage with its best-fit standard mixture. Errors can also increase in a more unpredictable way if the natural sediment contains minerals in addition to kaolinite and chlorite whose reflections interfere with the $3.5 \AA$ double peaks (Biscaye, 1964). Although imperfect, we have demonstrated that the doubled half-peak area approach is consistently more accurate than estimates from peak-intensity ratio and fitted-peak-area ratio.

\section{Application of the method}

The goal of refining the XRD methods for chlorite and kaolinite was to improve the detail of large data sets generated for NanTroSEIZE, without adding excessive amounts of time and complexity to sample preparation and data reduction. To test the utility of the doubled half-peak area approach, we took advantage of previously unpublished XRD data from ODP Sites 1177 and 1178 for which the reflections at $\sim 3.55 \AA$ had been recorded (Table T2). Kaolinite and chlorite contents for those specimens (in central and western Nankai Trough) were initially reported as one undifferentiated value, ranging from $0 \%$ to $32 \%$ of the clay-size fraction (Steurer and Underwood, 2003; Underwood and Steurer, 2003). Those authors, as well as Underwood et al. (1993), using samples from ODP Site 808, treated a small number of representative samples with acid to resolve how much kaolinite contributes to the composite $7 \AA$ peak area. Results from Sites 808 and 1173 show that kaolinite makes up $<20 \%$, and averages $\sim 14 \%$, of the chlorite-kaolinite composite (based on acid-treatment calculations). Three values from Site 1177 range from 10\% to 60\% kaolinite in the chlorite-kaolinite composite. Only 
one sample (190-1177A-46R-1, $120 \mathrm{~cm}$ ) was analyzed by both methods and yielded a value of $60 \%$ for the ratio of treated to untreated peak area, but it is worth noting that the total chlorite + kaolinite in this claysize fraction is only 4\% (Steurer and Underwood, 2003). For the same sample, we obtained a 50:50 ratio of kaolinite to chlorite using the doubled halfpeak area method (Table T2).

One justification for expanding the data set for the previously analyzed ODP samples from Nankai Trough is to ascertain whether or not the contents of kaolinite and chlorite changed systematically with time or stratigraphic position within the Shikoku Basin and Nankai trench wedge. Any such basinwide changes in the central and western Nankai Trough might have some bearing on interpretations of clay provenance and sediment dispersal for coeval strata within the NanTroSEIZE transect. To begin this comparison, we picked paleomagnetic polarity and calcareous nannofossil data from Sites 1177 and 1178 (Shipboard Scientific Party, 2001a, 2001b) and constructed composite age-depth models. Figure F6 shows how relative abundances of kaolinite and chlorite in the clay-size assemblage change as a function of time, as constrained by the age-depth models.

Most values of kaolinite are $<10 \%$ of the total claysize fraction, and chlorite content is typically $<20 \%$. Strata at Site 1177 cover an age range of 1.6 to 18.6 Ma, so those samples provide a better view of temporal trends. At Site 1177, the kaolinite and chlorite contents are significantly lower for strata that are older than $\sim 11 \mathrm{Ma}$, averaging only $\sim 2 \%$ of the claysize fraction. This depletion occurs is because the supply of smectite was much higher during the early to middle Miocene (Steurer and Underwood, 2003). The ratio of chlorite to kaolinite is also higher in these older strata. At Site 1178, chlorite values don't show any systematic stratigraphic trend, although this scatter of results over time is complicated by occurrences of several thrust faults and an unconformity. Over comparable ranges of time at the two sites, the relative abundance of kaolinite gradually decreases by roughly $8 \mathrm{wt} \%$ with age.

\section{Conclusions}

Tests of standard mineral mixtures show that best-fit regressions are nonlinear for plots of both peakintensity ratio and fitted-area ratio versus the concentration ratio of kaolinite and chlorite. Using the peak-intensity ratio method, accuracy improves if the chlorite to kaolinite ratio is close to 50:50. Using the fitted-area-ratio method, the results are more reliable when kaolinite contents are between $20 \%$ and $80 \%$. Our refined approach uses a doubled peak-area ratio.
This reduces the error to a maximum of $7.7 \%$ and an average of $2.6 \%$ because it avoids measuring minor peaks obscured by the dominant peak's shoulder. Either of two equations can be used, depending on which mineral is dominant. For kaolinite-dominant specimens, kaolinite $w t \%=100 \times(\mathrm{PA} / \mathrm{TA})^{1.613}$. For chlorite-dominant specimens, chlorite wt $\%=100 \times$ $(\mathrm{PA} / \mathrm{TA})^{1.433}$.

\section{Acknowledgments}

This research used samples acquired by the Ocean Drilling Program (ODP) during Leg 190. ODP was sponsored by the US National Science Foundation (NSF) and participating countries under management of Joint Oceanographic Institutions, Inc. Funding was provided by Joint Oceanographic Institutions, Inc., and the Consortium for Ocean Leadership through the US Science Support Program (grants F001281 and T315B58 to M. Underwood; grant T315C58 to J. Guo) and the NSF (grant OCE0751819). We thank Cedric John for his thoughtful review of the manuscript.

\section{References}

Biscaye, P.E., 1964. Distinction between kaolinite and chlorite in recent sediments by X-ray diffraction. Am. Miner., 49:1281-1289.

Biscaye, P.E., 1965. Mineralogy and sedimentation of recent deep-sea clay in the Atlantic Ocean and adjacent seas and oceans. Geol. Soc. Am. Bull., 76(7):803-831. doi:10.1130/0016-7606(1965)76[803:MASORD]2.0.CO;2

Brindley, G.W., 1961. Kaolin, serpentine and kindred minerals. In Brown, G. (Ed.), The X-ray Identification and Crystal Structures of Clay Minerals: London (Mineral. Soc.), 51-131.

Brindley, G.W., 1980. Quantitative X-ray mineral analysis of clays. In Brindley, G.W., and Brown, G.C. (Eds.), Crystal Structures of Clay Minerals and Their X-ray Identification. Mineral. Soc. Monogr., 5:411-438.

Chipera, S.J., and Bish, D.L., 2001. Baseline studies of the Clay Minerals Society source clays: powder X-ray diffraction analyses. Clays Clay Miner., 49(5):398-409. doi:10.1346/CCMN.2001.0490507

Cook, H.E., Johnson, P.D., Matti, J.C., and Zemmels, I., 1975. Methods of sample preparation and X-ray diffraction data analysis, X-ray Mineralogy Laboratory, Deep Sea Drilling Project, University of California, Riverside. In Hayes, D.E., Frakes, L.A., et al., Init. Repts. DSDP, 28: Washington (U.S. Govt. Printing Office), 999-1007. doi:10.2973/dsdp.proc.28.app4.1975

Elverhøi, A., and Rønningsland, T.M., 1978. Semiquantitative calculation of the relative amounts of kaolinite and chlorite by X-ray diffraction. Mar. Geol., 27(1-2):M19M23. doi:10.1016/0025-3227(78)90070-1 
Fagel, N., Boski, T., Likhoshway, L., and Oberhaensli, H., 2003. Late Quaternary clay mineral record in Central Lake Baikal (Academician Ridge, Siberia). Palaeogeogr., Palaeoclimatol., Palaeoecol., 193(1):159-179. doi:10.1016/S0031-0182(02)00633-8

Heath, G.R., and Pisias, N.G., 1979. A method for the quantitative estimation of clay minerals in North Pacific deep-sea sediments. Clays Clay Miner., 27(3):175184. doi:10.1346/CCMN.1979.0270302

Liu, Z., Trentesaux, A., Clemens, S.C., Colin, C., Wang, P., Huang, B., and Boulay, S., 2003. Clay mineral assemblages in the northern South China Sea: implications for East Asian monsoon evolution over the past 2 million years. Mar. Geol., 201(1-3):133-146. doi:10.1016/ S0025-3227(03)00213-5

Martin Vivaldi, J.L., and Gallego, M., 1961. Some problems in the identification of clay minerals in mixtures by $\mathrm{X}$ ray diffraction. I. Chlorite-kaolinite mixtures. Clay Miner. Bull., 4(26):288-292.

McManus, D.A., 1991. Suggestions for authors whose manuscripts include quantitative clay mineral analysis by Xray diffraction. Mar. Geol., 98(1):1-5. doi:10.1016/ 0025-3227(91)90030-8

Moore, D.M., and Reynolds, R.C., Jr., 1997. X-ray Diffraction and the Identification and Analysis of Clay Minerals (2nd ed.): Oxford (Oxford Univ. Press).

Nelson, B.W., and Roy, R., 1953. New data on the composition and identification of chlorites. Clays Clay Miner., 2(1):335-348. doi:10.1346/CCMN.1953.0020127

Omotoso, O., McCarty, D.K., Hillier, S., and Kleeberg, R., 2006. Some successful approaches to quantitative mineral analysis as revealed by the 3rd Reynolds Cup contest. Clays Clay Miner., 54(6):748-760. doi:10.1346/ CCMN.2006.0540609

Ottner, F., Gier, S., Kuderna, M., and Schwaighofer, B., 2000. Results of an inter-laboratory comparison of methods for quantitative clay analysis. Appl. Clay Sci., 17(5-6): 223-243. doi:10.1016/S0169-1317(00)00015-6

Petschick, R., Kuhn, G., and Gingele, F., 1996. Clay mineral distribution in surface sediments of the South Atlantic: sources, transport, and relation to oceanography. Mar. Geol., 130(3-4):203-229. doi:10.1016/00253227(95)00148-4

Reynolds, R.C., 1989. Principles and techniques of quantitative analysis of clay minerals by X-ray powder diffraction. In Pevear, D.R., and Mumpton, F.A. (Eds.), Quantitative Mineral Analysis of Clays. CMS Workshop Lect., 1:4-36.

Shipboard Scientific Party, 2001a. Site 1177. In Moore, G.F., Taira, A., Klaus, A., et al., Proc. ODP, Init. Repts., 190: College Station, TX (Ocean Drilling Program), 1-91. doi:10.2973/odp.proc.ir.190.108.2001

Shipboard Scientific Party, 2001b. Site 1178. In Moore, G.F., Taira, A., Klaus, A., et al., Proc. ODP, Init. Repts., 190: College Station, TX (Ocean Drilling Program), 1108. doi:10.2973/odp.proc.ir.190.109.2001
Snyder, R.L., and Bish, D.L., 1989. Quantitative analysis. In Bish, D.L., and Post, J.E. (Eds.), Modern Powder Diffraction. Rev. Mineral., 20:101-144.

Środoń, J., 2002. Quantitative mineralogy of sedimentary rocks with emphasis on clays and with applications to K-Ar dating. Mineral. Mag., 66(5):677-687. doi:10.1180/ 0026461026650055

Środoń, J., Drits, V.A., McCarty, D.K., Hsieh, J.C.C., and Eberl, D.D., 2001. Quantitative X-ray diffraction analysis of clay-bearing rocks from random preparations. Clays Clay Miner., 49(6):514-528. http://ccm.geoscienceworld.org/cgi/content/abstract/49/6/514

Steurer, J.F., and Underwood, M.B., 2003. Clay mineralogy of mudstones from the Nankai Trough reference Sites 1173 and 1177 and frontal accretionary prism Site 1174. In Mikada, H., Moore, G.F., Taira, A., Becker, K., Moore, J.C., and Klaus, A. (Eds.), Proc. ODP, Sci. Results, 190/196: College Station, TX (Ocean Drilling Program), 1-37. doi:10.2973/odp.proc.sr.190196.211.2003

Svensson, A., Biscaye, P.E., and Grousset, F.E., 2000. Characterization of late glacial continental dust in the Greenland Ice Core Project ice core. J. Geophys. Res., [Atmospheres], 105(D4):4637-4656. doi:10.1029/ 1999JD901093

Underwood, M., Basu, N., Steurer, J., and Udas, S., 2003. Data report: normalization factors for semiquantitative X-ray diffraction analysis, with application to DSDP Site 297, Shikoku Basin. In Mikada, H., Moore, G.F., Taira, A., Becker, K., Moore, J.C., and Klaus, A. (Eds.), Proc. ODP, Sci. Results, 190/196: College Station, TX (Ocean Drilling Program), 1-28. doi:10.2973/ odp.proc.sr.190196.203.2003

Underwood, M.B., Orr, R., Pickering, K., and Taira, A., 1993. Provenance and dispersal patterns of sediments in the turbidite wedge of Nankai Trough. In Hill, I.A., Taira, A., Firth, J.V., et al., Proc. ODP, Sci. Results, 131: College Station, TX (Ocean Drilling Program), 15-34. doi:10.2973/odp.proc.sr.131.105.1993

Underwood, M.B., and Steurer, J.F., 2003. Composition and sources of clay from the trench slope and shallow accretionary prism of Nankai Trough. In Mikada, H., Moore, G.F., Taira, A., Becker, K., Moore, J.C., and Klaus, A. (Eds.), Proc. ODP, Sci. Results, 190/196: College Station, TX (Ocean Drilling Program), 1-28. doi:10.2973/ odp.proc.sr.190196.206.2003

Vogt, C., Lauterjung, J., and Fischer, R.X., 2002. Investigation of the clay fraction $(<2 \mu \mathrm{m})$ of the Clay Mineral Society reference clays. Clays Clay Miner., 50(3):388400. doi:10.1346/000986002760833765

Initial receipt: 23 April 2010

Acceptance: 9 September 2011

Publication: 4 November 2011

MS 314315316-201 
Figure F1. Example of correction of X-ray diffractogram for a typical kaolinite and chlorite standard mixture. Kaolinite (002) peak is gray. The first step moves the original chlorite (004) peak crest (green) to $25.1^{\circ} 2 \theta$ (red). Separation between kaolinite (002) and chlorite (004) is fixed at $0.27^{\circ} 2 \theta$, after which the obscured kaolinite (002) peak intensity can be picked. Both peaks are then modeled using the Pearson II peak fitting function.

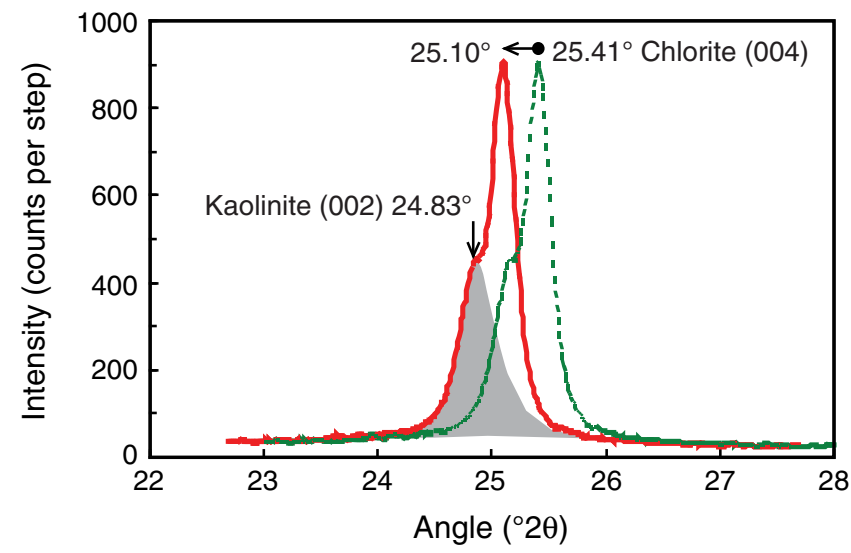


Figure F2. X-ray diffractogram of a typical kaolinite and chlorite standard mixture. The regions highlighted in gray show how to measure the half peak area and the total peak area. The dashed line helps outline the dominant peak.
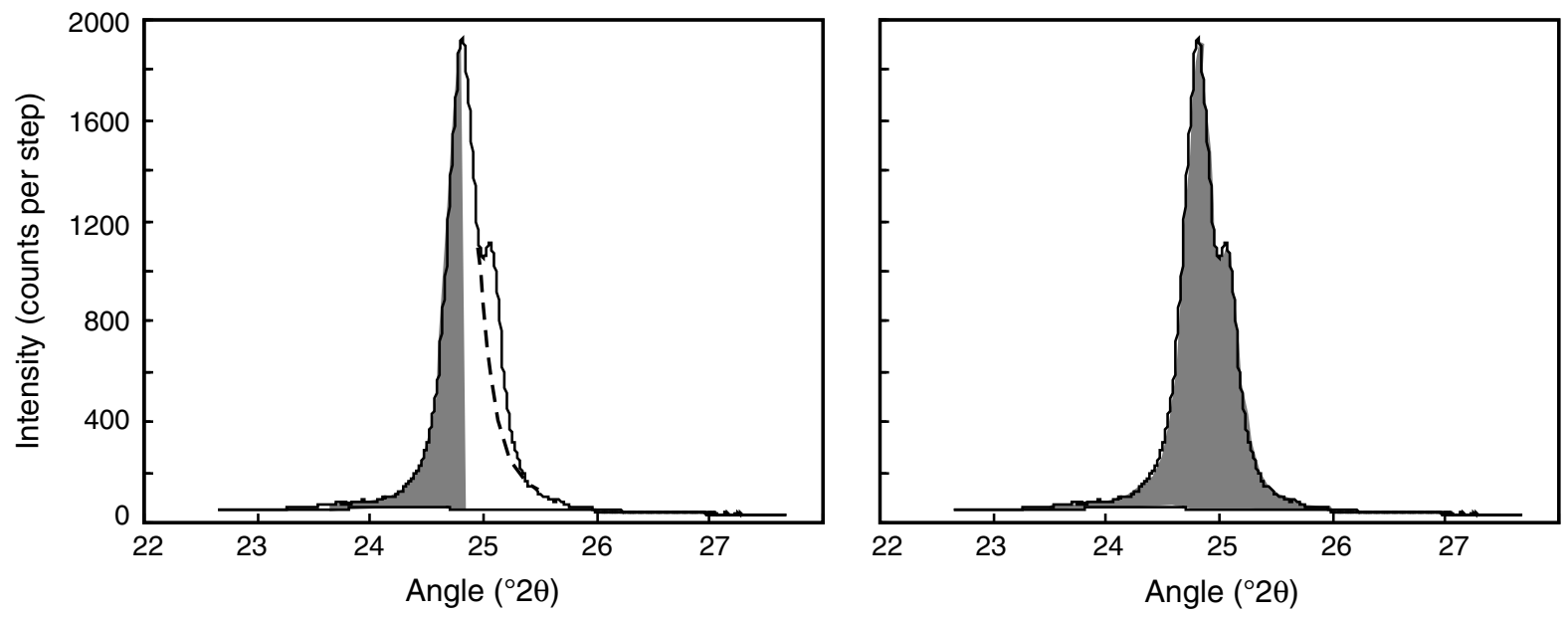
Figure F3. X-ray diffractograms of all kaolinite and chlorite standard mixtures used in this study. Numbers refer to known mineral percentages by weight. (Continued on next page.)
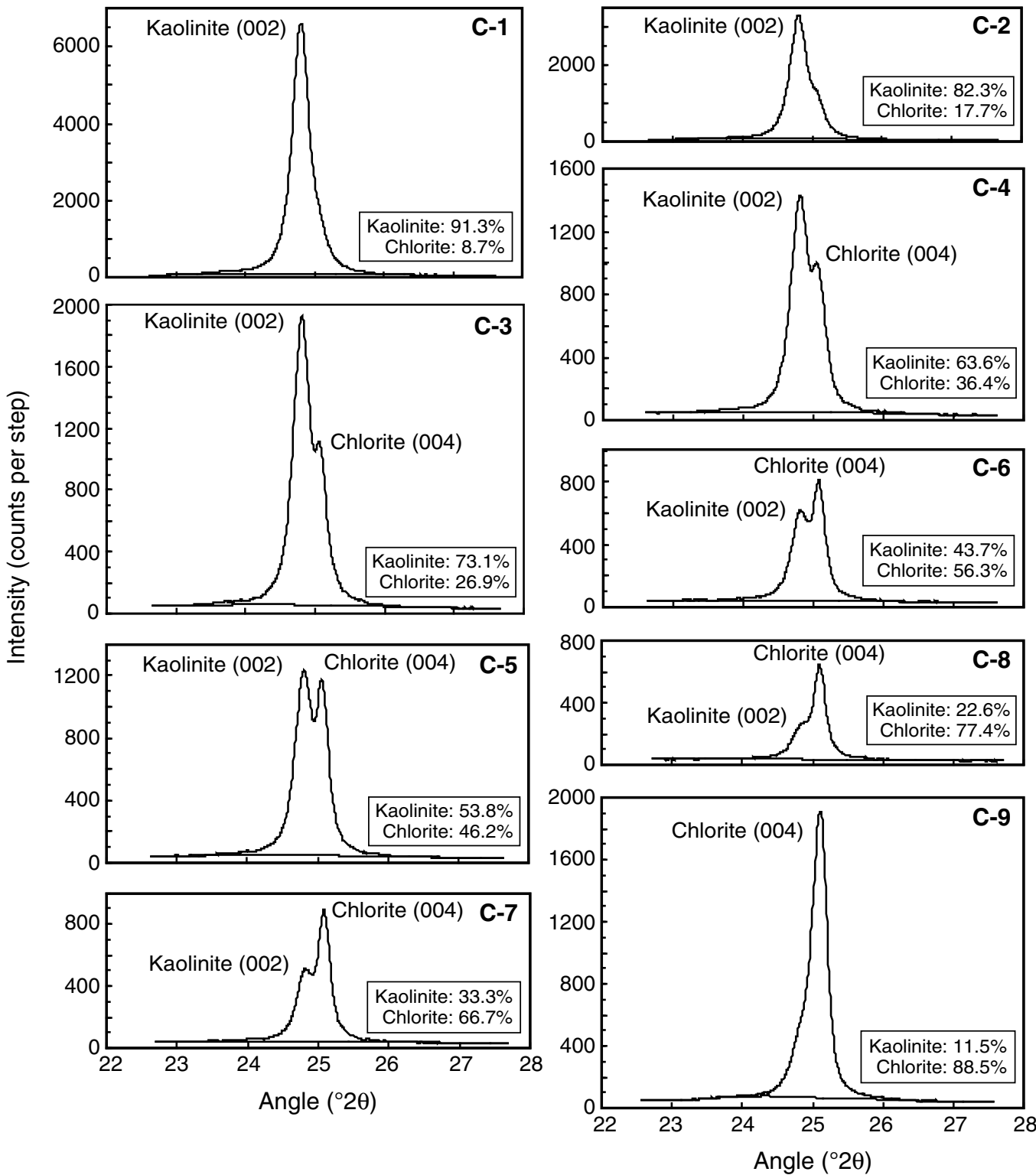
Figure F3 (continued).
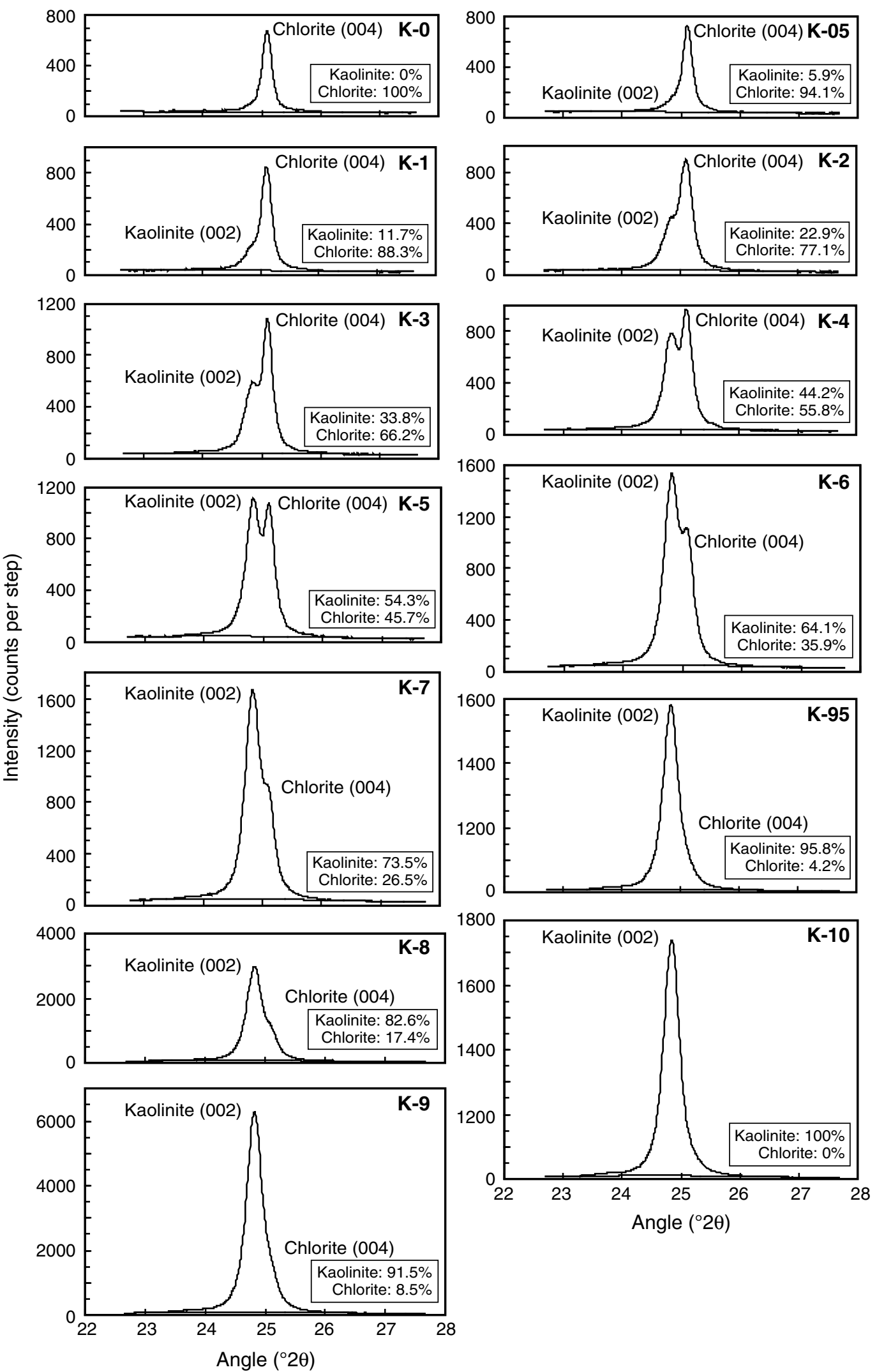

Angle $\left({ }^{\circ} 2 \theta\right)$ 
Figure F4. Plots of kaolinite and chlorite abundances versus peak-area ratios. The solid curves represent best fit power-law regression. Dashed lines represent linear regressions. $r=$ correlation coefficient.

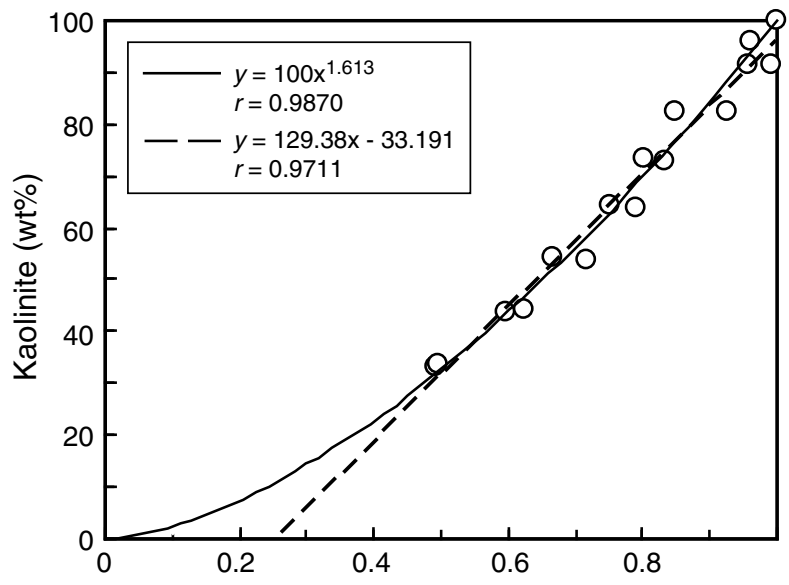

Kaolinite peak area/composite peak area

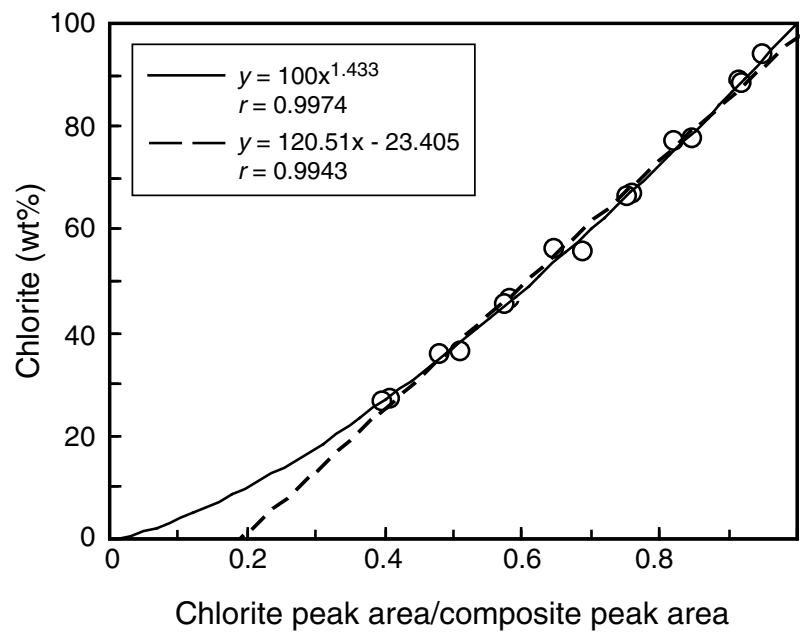


Figure F5. Plots of comparison of errors (known weight percent vs. calculated weight percent) from three different methods. Errors are consistently smaller using half-peak areas.

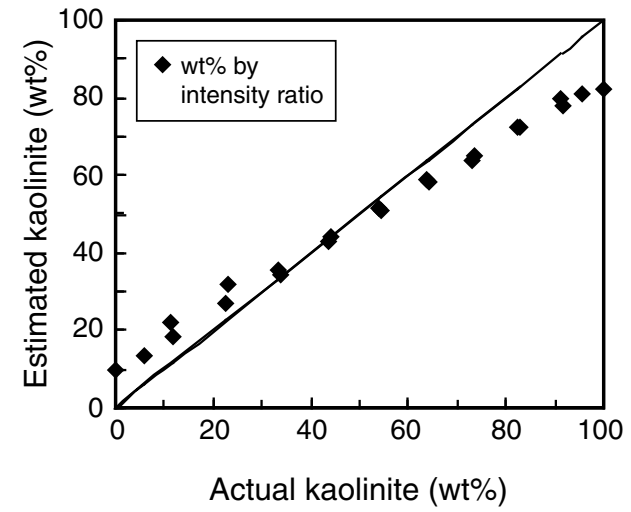

Actual kaolinite (wt\%)
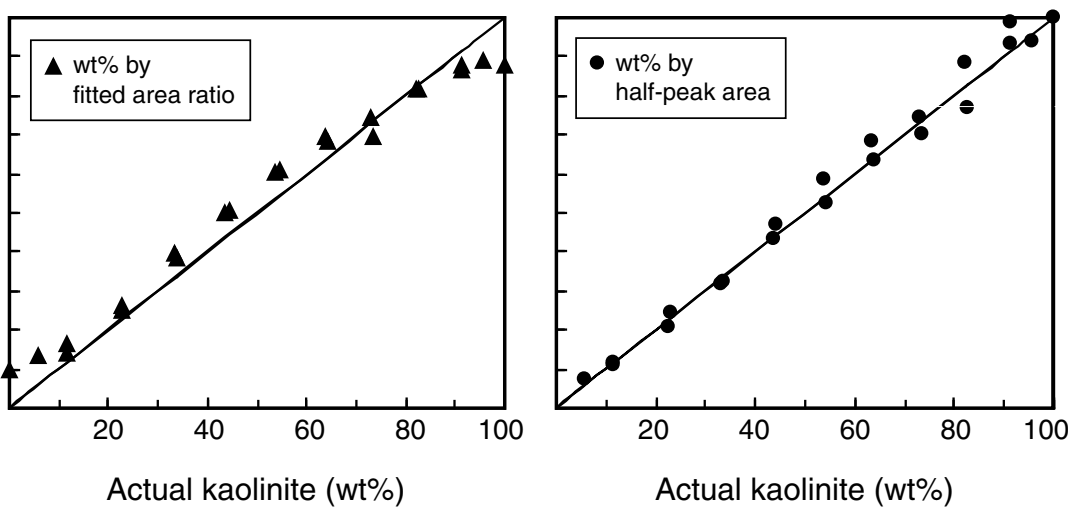
Figure F6. Plots of temporal changes in relative abundances of chlorite and kaolinite within the clay-size fraction and abundance ratio of chlorite to kaolinite in mud and mudstone from ODP Sites 1177 and 1178. Age control from Shipboard Scientific Party (2001a, 2001b).
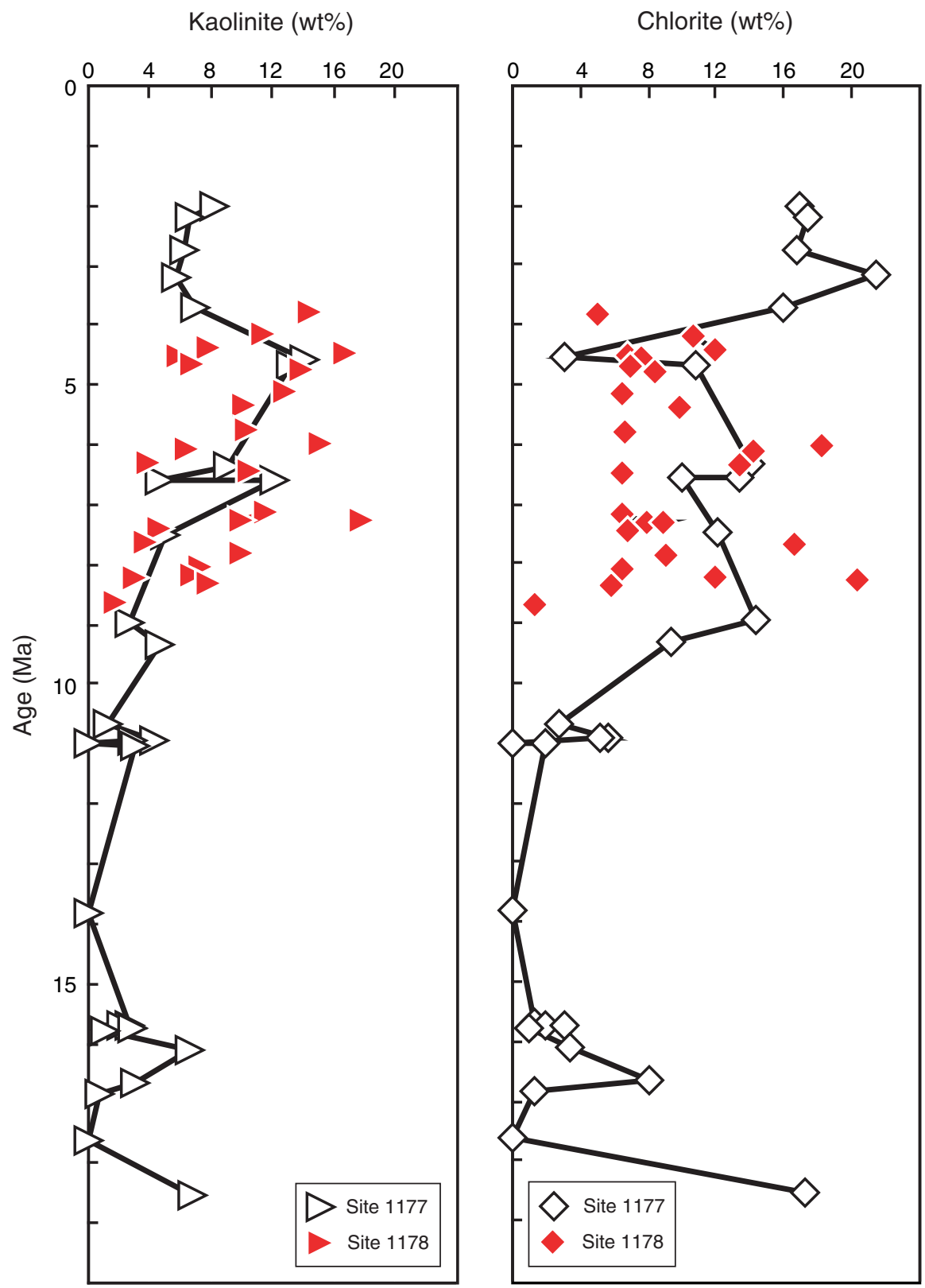

Chlorite/Kaolinite

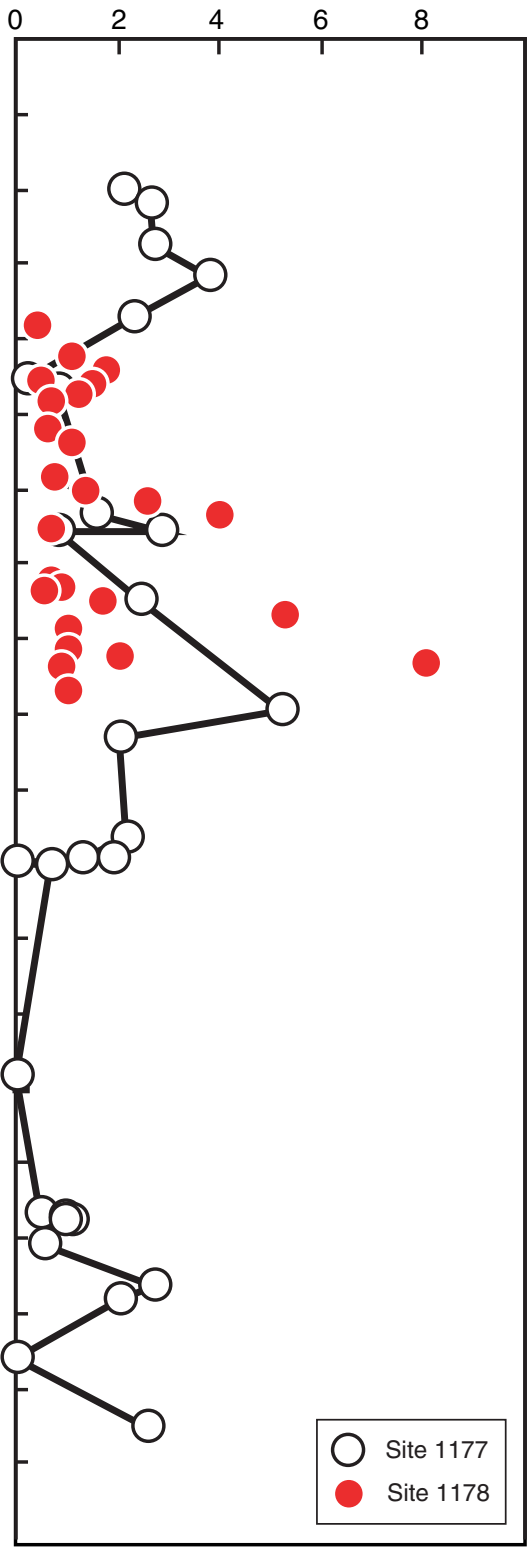




\begin{tabular}{|c|c|c|c|c|c|c|c|c|c|c|c|c|c|c|c|}
\hline \multirow[b]{2}{*}{ Mixture } & \multicolumn{2}{|c|}{$\begin{array}{c}\text { Actual abundance } \\
\text { (wt\%) }\end{array}$} & \multicolumn{2}{|c|}{$\begin{array}{l}\begin{array}{l}\text { Peak intensity } \\
\text { (counts/step) }\end{array} \\
\end{array}$} & \multicolumn{2}{|c|}{$\begin{array}{c}\text { Fitted peak } \\
\text { (total count) }\end{array}$} & \multicolumn{3}{|c|}{$\begin{array}{l}\text { Doubled half-peak and composite peak area } \\
\text { (total count) }\end{array}$} & \multicolumn{6}{|c|}{$\begin{array}{l}\text { Calculated kaolinite abundances and errors } \\
\text { (wt\%) }\end{array}$} \\
\hline & Kaolinite & Chlorite & $\begin{array}{l}\text { Kaolinite } \\
(002)\end{array}$ & $\begin{array}{c}\text { Chlorite } \\
(004)\end{array}$ & $\begin{array}{l}\text { Kaolinite } \\
(002)\end{array}$ & $\begin{array}{l}\text { Chlorite } \\
(004)\end{array}$ & $\begin{array}{l}\text { Kaolinite } \\
(002)\end{array}$ & $\begin{array}{l}\text { Chlorite } \\
(004)\end{array}$ & $\begin{array}{l}\text { Kaolinite }(002)+ \\
\text { chlorite }(004)\end{array}$ & $\begin{array}{l}\text { Intensity } \\
\text { ratio }\end{array}$ & $\begin{array}{c}\text { Error- } \\
\text { intensity ratio }\end{array}$ & $\begin{array}{l}\text { Fitted-area } \\
\text { ratio }\end{array}$ & $\begin{array}{l}\text { Error-fitted } \\
\text { area ratio }\end{array}$ & $\begin{array}{l}\text { Doubled half- } \\
\text { peak area }\end{array}$ & $\begin{array}{l}\text { Error-half- } \\
\text { peak area }\end{array}$ \\
\hline$C-1$ & 91.3 & 8.7 & 6,515 & 1,682 & 225,627 & 31,479 & 127,691 & NA & 256,933 & 79.5 & 11.8 & 87.8 & 3.5 & 99.0 & 7.7 \\
\hline$C-2$ & 82.3 & 17.7 & 3,215 & 1,220 & 110,471 & 24,640 & 62,721 & NA & 135,634 & 72.5 & 9.8 & 81.8 & 0.6 & 88.2 & 5.8 \\
\hline$C-3$ & 73.1 & 26.9 & 1,870 & 1,057 & 63,138 & 21,927 & 35,892 & 17,663 & 86,096 & 63.9 & 9.2 & 74.2 & 1.1 & 74.6 & 1.5 \\
\hline$C-4$ & 63.6 & 36.4 & 1,379 & 952 & 47,991 & 21,213 & 27,800 & 18,009 & 70,457 & 59.2 & 4.4 & 69.3 & 5.7 & 68.3 & 4.7 \\
\hline C-5 & 53.8 & 46.2 & 1,182 & 1,122 & 39,371 & 25,531 & 23,670 & 19,264 & 65,868 & 51.3 & 2.5 & 60.7 & 6.9 & 58.7 & 4.9 \\
\hline$C-6$ & 43.7 & 56.3 & 577 & 766 & 18,730 & 18,531 & 11,262 & 12,259 & 37,766 & 43.0 & 0.7 & 50.3 & 6.6 & 43.4 & 0.3 \\
\hline C-7 & 33.3 & 66.7 & 467 & 849 & 13,643 & 20,969 & 8,598 & 13,289 & 34,942 & 35.5 & 2.2 & 39.4 & 6.1 & 31.9 & 1.4 \\
\hline$C-8$ & 22.6 & 77.4 & 223 & 607 & 5,485 & 16,615 & NA & 9,332 & 21,961 & 26.9 & 4.3 & 24.8 & 2.3 & 20.8 & 1.8 \\
\hline C-9 & 11.5 & 88.5 & 496 & 1,761 & 8,782 & 54,812 & NA & 29,134 & 63,600 & 22.0 & 10.5 & 13.8 & 2.4 & 11.8 & 0.3 \\
\hline $\mathrm{K}-0$ & 0.0 & 100.0 & 69 & 640 & 1,673 & 15,958 & NA & 8,855 & 17,143 & 9.7 & 9.7 & 9.5 & 9.5 & -4.8 & 4.8 \\
\hline K-05 & 5.9 & 94.1 & 107 & 676 & 2,713 & 17,159 & NA & 9,367 & 19,723 & 13.7 & 7.8 & 13.7 & 7.8 & 7.1 & 1.2 \\
\hline K-1 & 11.7 & 88.3 & 183 & 811 & 4,411 & 22,114 & NA & 12,329 & 26,786 & 18.4 & 6.7 & 16.6 & 4.9 & 11.2 & 0.5 \\
\hline $\mathrm{K}-2$ & 22.9 & 77.1 & 402 & 868 & 9,908 & 27,539 & NA & 15,310 & 37,204 & 31.7 & 8.7 & 26.5 & 3.5 & 24.4 & 1.4 \\
\hline $\mathrm{K}-3$ & 33.8 & 66.2 & 551 & 1,039 & 16,064 & 25,867 & 10,638 & 16,084 & 42,769 & 34.7 & 0.9 & 38.3 & 4.5 & 32.4 & 1.4 \\
\hline K-4 & 44.2 & 55.8 & 737 & 930 & 23,765 & 23,039 & 14,846 & 16,401 & 47,516 & 44.2 & 0.0 & 50.8 & 6.5 & 46.8 & 2.6 \\
\hline K-5 & 54.3 & 45.7 & 1,063 & 1,037 & 36,160 & 23,057 & 20,057 & 17,279 & 59,999 & 50.6 & 3.7 & 61.1 & 6.7 & 52.2 & 2.1 \\
\hline $\mathrm{K}-6$ & 64.1 & 35.9 & 1,487 & 1,065 & 51,487 & 24,232 & 28,895 & 18,484 & 76,850 & 58.3 & 5.8 & 68.0 & 3.9 & 63.1 & 1.0 \\
\hline K-7 & 73.5 & 26.5 & 1,620 & 870 & 53,500 & 23,317 & 30,854 & 15,270 & 76,814 & 65.1 & 8.5 & 69.6 & 3.9 & 70.2 & 3.3 \\
\hline $\mathrm{K}-8$ & 82.6 & 17.4 & 2,914 & 1,106 & 102,934 & 22,973 & 53,545 & NA & 126,280 & 72.5 & 10.2 & 81.8 & 0.9 & 76.7 & 6.0 \\
\hline K-9 & 91.5 & 8.5 & 6,200 & 1,731 & 220,796 & 34,478 & 122,081 & NA & 255,051 & 78.2 & 13.3 & 86.5 & 5.0 & 93.2 & 1.7 \\
\hline & 95.8 & 4.2 & 5,714 & 1,358 & 203,069 & 25,808 & 110,104 & NA & 229,221 & 80.8 & 15.0 & 88.7 & 7.0 & 93.7 & 2.0 \\
\hline \multirow[t]{2}{*}{$\mathrm{K}-10$} & 100.0 & 0.0 & 7,270 & 1,552 & 259,775 & 36,568 & 147,478 & NA & 295,334 & 82.4 & 17.6 & 87.7 & 12.3 & 99.8 & 0.2 \\
\hline & & & & & & & & & & Average: & 7.4 & & 5.1 & & 2.6 \\
\hline
\end{tabular}

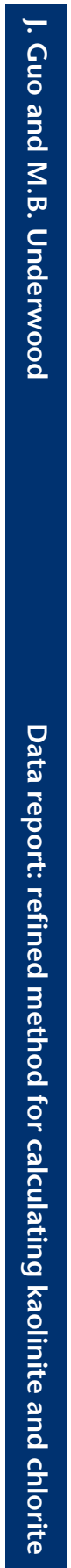

NA = Not applicable. 
Table T2. X-ray diffraction analysis showing kaolinite and chlorite content in mud and mudstone $(<2 \mu \mathrm{m}$ fraction) from ODP Sites 1177 and 1178.

\begin{tabular}{|c|c|c|c|c|c|c|c|c|c|c|}
\hline \multirow{3}{*}{$\begin{array}{l}\text { Hole, core, section, } \\
\text { interval }(\mathrm{cm})\end{array}$} & \multirow{3}{*}{$\begin{array}{l}\text { Depth } \\
\text { (mbsf) }\end{array}$} & \multicolumn{4}{|c|}{ Abundance (wt\%) } & \multicolumn{3}{|c|}{ Peak area (total counts) } & \multirow{2}{*}{\multicolumn{2}{|c|}{ Relative abundance (wt\%) }} \\
\hline & & & & Chlorite + & & Half & Half & Total & & \\
\hline & & Smectite & Illite & kaolinite & Quartz & kaolinite & chlorite & area & Kaolinite & Chlorite \\
\hline \multicolumn{11}{|l|}{190} \\
\hline 1177A-1R-2, 82 & 302.52 & 32 & 36 & 25 & 7 & 1439 & NM & 5778 & 8 & 17 \\
\hline 1177A-2R-2, 111 & 311.81 & 22 & 33 & 24 & 21 & NM & 1071 & 2678 & 7 & 17 \\
\hline 1177A-5R-5, 123 & 343.83 & 30 & 38 & 23 & 9 & NM & 1858 & 4636 & 6 & 17 \\
\hline 1177A-8R-2, 30 & 368.80 & 24 & 39 & 27 & 10 & NM & 1695 & 3990 & 6 & 21 \\
\hline 1177A-10R-2, 118 & 388.79 & 31 & 35 & 23 & 10 & NM & 1707 & 4399 & 7 & 16 \\
\hline 1177A-11R-CC, 10 & 403.75 & 40 & 39 & 17 & 3 & 2712 & NM & 6120 & 14 & 3 \\
\hline $1177 \mathrm{~A}-12 \mathrm{R}-1,44$ & 405.74 & 30 & 30 & 24 & 16 & NM & 847 & 2945 & 13 & 11 \\
\hline 1177A-16R-3, 119 & 448.09 & 34 & 33 & 23 & 10 & NM & 1956 & 5533 & 9 & 14 \\
\hline 1177A-17R-1, 118 & 454.68 & 41 & 35 & 18 & 5 & NM & 2096 & 5174 & 5 & 13 \\
\hline 1177A-17R-2, 26 & 455.26 & 36 & 35 & 22 & 7 & NM & 828 & 2885 & 12 & 10 \\
\hline 1177A-20R-1, 104 & 483.44 & 29 & 32 & 17 & 22 & 616 & NM & 2650 & 5 & 12 \\
\hline 1177A-24R-5, 128 & 527.68 & 46 & 29 & 17 & 8 & NM & 1723 & 3893 & 3 & 14 \\
\hline 1177A-25R-6, 105 & 538.95 & 44 & 35 & 14 & 7 & 1197 & NM & 4731 & 5 & 9 \\
\hline 1177A-30R-2, 30 & 580.30 & 65 & 20 & 4 & 11 & NM & 950 & 2477 & 1 & 3 \\
\hline 1177A-30R-7, 29 & 587.79 & 54 & 26 & 10 & 10 & NM & 999 & 2977 & 4 & 6 \\
\hline 1177A-30R-7, 35 & 587.85 & 59 & 24 & 8 & 8 & NM & 1175 & 3169 & 3 & 5 \\
\hline $1177 \mathrm{~A}-31 \mathrm{R}-2,57$ & 590.27 & 87 & 9 & 0 & 4 & NM & 520 & 1855 & 0 & 0 \\
\hline 1177A-31R-CC, 8 & 591.10 & 70 & 18 & 5 & 8 & NM & 668 & 2534 & 3 & 2 \\
\hline 1177A-40R-1, 115 & 675.95 & 75 & 19 & 0 & 6 & 1015 & NM & 2782 & 0 & 0 \\
\hline 1177A-46R-1, 18 & 732.68 & 69 & 19 & 4 & 8 & 995 & NM & 2513 & 3 & 1 \\
\hline 1177A-46R-1, 120 & 733.70 & 66 & 19 & 4 & 12 & 627 & NM & 1898 & 2 & 2 \\
\hline 1177A-46R-2, 122 & 735.22 & 64 & 15 & 6 & 15 & 687 & NM & 2161 & 3 & 3 \\
\hline 1177A-46R-3, 9 & 735.59 & 71 & 20 & 2 & 8 & NM & 703 & 2336 & 1 & 1 \\
\hline 1177A-47R-3, 101 & 746.11 & 54 & 21 & 10 & 15 & NM & 702 & 2962 & 7 & 3 \\
\hline 1177A-49R-1, 61 & 761.91 & 41 & 30 & 11 & 18 & 320 & NM & 1439 & 3 & 8 \\
\hline 1177A-49R-5, 72 & 768.02 & 65 & 22 & 2 & 12 & NM & 255 & 675 & 1 & 1 \\
\hline $1177 \mathrm{~A}-52 \mathrm{R}-2,56$ & 792.36 & 91 & 9 & 0 & 0 & 340 & NM & 999 & 0 & 0 \\
\hline 1177A-55R-1, 92 & 820.12 & 27 & 35 & 24 & 13 & NM & 1821 & 4583 & 7 & 17 \\
\hline 1178A-9X-5, 129 & 72.03 & 50 & 30 & 18 & 2 & 1559 & NM & 3840 & 13 & 5 \\
\hline 1178A-13X-4, 132 & 109.82 & 45 & 27 & 21 & 7 & NM & 1676 & 5340 & 10 & 11 \\
\hline 1178A-15X-4, 130 & 129.00 & 45 & 26 & 19 & 10 & NM & 1822 & 5004 & 7 & 12 \\
\hline 1178A-16X-4, 128 & 138.48 & 47 & 28 & 22 & 4 & 2526 & NM & 6400 & 15 & 7 \\
\hline 1178A-17X-2, 125 & 144.95 & 59 & 21 & 13 & 6 & 1756 & NM & 6182 & 5 & 8 \\
\hline $1178 \mathrm{~A}-18 \mathrm{X}-4,130$ & 156.46 & 62 & 24 & 13 & 2 & NM & 1827 & 5604 & 6 & 7 \\
\hline 1178A-19X-3, 125 & 165.65 & 43 & 28 & 21 & 8 & 1762 & NM & 4875 & 12 & 9 \\
\hline 1178A-23X-2, 117 & 201.87 & 42 & 18 & 18 & 22 & NM & 568 & 2283 & 11 & 7 \\
\hline 1178A-25X-2, 118 & 221.05 & 52 & 24 & 19 & 5 & 1742 & NM & 5527 & 9 & 10 \\
\hline 1178A-29X-3, 122 & 260.93 & 61 & 18 & 16 & 5 & 1747 & NM & 4906 & 9 & 7 \\
\hline 1178A-31X-4, 116 & 281.86 & 27 & 33 & 32 & 8 & NM & 2405 & 7073 & 14 & 18 \\
\hline 1178A-43X-1, 121 & 392.81 & 55 & 22 & 17 & 6 & 2300 & NM & 6261 & 10 & 7 \\
\hline $1178 \mathrm{~B}-3 \mathrm{R}-3,147$ & 404.47 & 46 & 30 & 17 & 7 & NM & 1603 & 5384 & 9 & 8 \\
\hline 1178A-44X-5, 117 & 407.69 & 44 & 21 & 25 & 9 & 2142 & NM & 5660 & 16 & 9 \\
\hline $1178 \mathrm{~B}-5 \mathrm{R}-1,114$ & 420.44 & 59 & 26 & 11 & 4 & NM & 2099 & 5805 & 4 & 7 \\
\hline 1178B-8R-5, 147 & 456.37 & 46 & 27 & 18 & 10 & NM & 595 & 1915 & 9 & 9 \\
\hline 1178B-12R-4, 112 & 492.32 & 35 & 38 & 18 & 9 & NM & 2115 & 5586 & 6 & 12 \\
\hline $1178 \mathrm{~B}-13 \mathrm{R}-2,80$ & 498.70 & 38 & 26 & 23 & 13 & NM & 2886 & 6265 & 3 & 20 \\
\hline $1178 \mathrm{~B}-14 \mathrm{R}-1,94$ & 506.94 & 76 & 15 & 3 & 6 & NM & 1130 & 3648 & 1 & 2 \\
\hline 1178B-15R-5, 103 & 522.63 & 69 & 16 & 13 & 2 & NM & 2066 & 7091 & 7 & 6 \\
\hline 1178B-17R-1, 105 & 535.85 & 62 & 23 & 13 & 2 & NM & 1890 & 6109 & 6 & 7 \\
\hline 1178B-19R-2, 144 & 556.94 & 44 & 17 & 20 & 20 & NM & 1848 & 4175 & 3 & 17 \\
\hline 1178B-25R-2, 98 & 614.18 & 53 & 19 & 16 & 11 & NM & 1418 & 5248 & 9 & 7 \\
\hline 1178B-26R-1, 116 & 622.56 & 46 & 32 & 17 & 5 & NM & 2376 & 5553 & 3 & 14 \\
\hline 1178B-27R-1,98 & 631.98 & 35 & 35 & 20 & 10 & NM & 2101 & 5284 & 6 & 14 \\
\hline
\end{tabular}

Values within clay-size fraction are from Steurer and Underwood (2003) and Underwood and Steurer (2003) and were calculated using singular value decomposition normalization factors of Underwood et al. (2003). NM = not measured. 